terror suspects, look similar to other attacks linked to al-Qaeda, such as the Bali bombings of 2002. That campaign will continue as the group attempts to oust US troops from the Middle East, says Pape.

But Merari believes there will be no largescale campaign of the type seen in Iraq and Israel. "The London bombers do not represent the sentiments of their community," he explains. This lack of support makes it harder for terrorist groups to recruit and easier for police to gather information on suspects. As the group leaders usually have to operate from abroad, it also increases the time needed to plan an attack. "This doesn't mean that more attacks will not occur," says Merari. "But there will not be a wave of them."

\section{Calculated risk}

Andrew Coburn, director of terrorism research for Risk Management Solutions in Cambridge, UK, uses risk-analysis techniques borrowed from the fields of economics and natural disasters to predict terrorist risk for insurance companies. Understanding that the attackers are, in a sense, sane and rational is key to predicting where they might strike and what damage they will inflict, he says.

"Logic drives their actions," he says. "They're not madmen. They're just playing to a different rule book."

Coburn and his colleagues have developed a terrorism risk model that scores different attacks on the basis of how easy they are to carry out versus how much damage they will inflict - not only in terms of human life, but also in economics and the symbolic value of the target.

"It doesn't predict where attacks will happen, but it suggests the kinds of targets," says Coburn. "There are not many locations in the world where you can guarantee 100 people within four metres of your explosion in one of the least welldefended areas, such as a tube train."

Coburn believes that, after an initial period of particularly high security, when the danger is seen as diminished, the risk to London will remain high for years to come. He does not rule out the possibility of terrorists attempting a far larger attack that, although more difficult to pull off, could claim far more lives than the 56 who perished earlier this month.

This was Western Europe's first suicide attack, and Coburn also sees that trend moving gradually westwards. "The risk is spreading from the Middle East, through Europe and into the United States," he says. But he maintains that London can pull off a safe Olympic Games in 2012. "When we go all out and crank up the protection for an event, people tend not to attack."

Jim Giles and Michael Hopkin

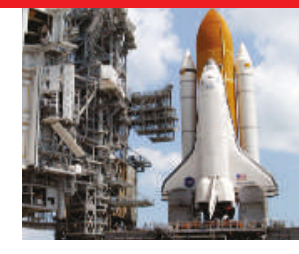

NASA'S DISCOVERY SHUTTLE GROUNDED Faulty fuel sensor puts launch on hold. Read all about the mission online. www.nature.com/news

\title{
Altered embryos offered as solution to stem-cell rift
}

\section{WASHINGTON DC}

US lawmakers were last week gathering support for legislation that would ease federal restrictions on funding for embryonic stem-cell research.

Public polls favour the bill, which passed by a large bipartisan majority in the House of Representatives on 24 May (see Nature 435, 544-545; 2005). But President George W. Bush is dead against it. That left many senators in the Republican party in a quandary: how could they back a popular measure without alienating pro-life voters and the US president?

Into this fray stepped William Hurlbut, a consulting professor in human biology at Stanford University who serves on the President's Council on Bioethics. At a Senate hearing on 12 July, Hurlbut told lawmakers to back research into the creation of embryo-like entities that have been engineered to lack the capacity to develop into human babies, for example by mutating certain genes.

Hurlbut has proposed that scientists create these entities in a process he calls "altered nuclear transfer", to distinguish it from somatic cell nuclear transfer, which scientists use to create human embryos from which stem cells can be extracted.

Such entities lack the moral status of human embryos, argues Hurlbut, and so could be used for research with fewer ethical objections. "We should find a way to go forward with our biomedical research that gathers in our whole nation," he told the Senate.

Although Hurlbut sees himself as a unifying force, many stem-cell researchers are worried. His proposal has not been tested, and the idea of purposely creating defective embryos has met with serious objections from ethicists.

But it is a gift for politicians who are undecided about stem-cell research. Senate leaders, encouraged by the White House, have begun pushing for laws backing such alternatives to embryonic stem-cell research. The proposals threaten to erode support for the measure to loosen funding restrictions on stem-cell research itself.

Despite opposing the use of embryos for stem-cell research, Hurlbut describes himself as "very pro-science". He attended
IMAGE

UNAVAILABLE FOR COPYRIGHT REASONS

William Hurlbut believes embryo-like entities offer a way forward for stem-cell research.

Stanford Medical School, but abandoned plans to practise medicine when his first child was born with severe brain damage.

As a result, Hurlbut decided to devote his career to teaching and studying the ethics of biomedicine. One of his heroes became Saint Francis of Assisi, whose life of poverty was characterized by a love of nature. "I thought, this is exactly what the world needs right now," Hurlbut says. "We were ravaging the natural world, and it was obvious that we were ramping up to ravage and reorder the human body as well."

Joining the President's Council on Bioethics in 2002, Hurlbut says he felt torn between the supporters and opponents of embryonic stem-cell research, and proposed altered nuclear transfer as a way to bridge the divide.

He warns that the debate over stem cells could be the first of a series of battles over the use of powerful techniques in developmental biology. He believes scientists must forge harmony with their opponents or risk losing support and funding for their work.

"If we don't have a solid frame from which we can go forward, there's just going to be an endless series of bitter disputes," Hurlbut says. "I'm trying to provide one little island of unity in a large sea of controversy."

As Nature went to press, negotiators were still trying to decide how to bring the stem-cell legislation before the full Senate for a vote this week.

Erika Check 